\title{
Alfons FÜRST, Hieronymus. Askese und Wissenschaft in der Spätantike, Freiburg in Breisgau 2003, Herder, ss. 335.
}

Św. Hieronim jest bez wątpienia jedną $\mathrm{z}$ najbardziej znanych i zarazem najbardziej barwnych postaci starożytności chrześcijańskiej. Pozostawiona przez niego bogata spuścizna literacka oraz zachowane świadectwa ludzi jemu współczesnych dostarczają nadzwyczaj dużo materiału przydatnego do opracowania jego biografii. Nic zatem dziwnego, że powstają coraz to nowe biografie tego Ojca Kościoła. Książka Alfonsa Fürsta jest kolejną, jaka się ukazała w ostatnich latach.

Książka składa się $z$ trzech części. Pierwsza część stanowi właściwe opracowanie, od którego pochodzi tytuł. Autor bez zaprzątania sobie głowy przedstawianiem biografii św. Hieronima, próbuje ukazać jego postać poprzez najbardziej - zdaniem autora - charakterystyczne elementy osobowości i umysłowości biblisty z Betlejem. Zwraca zatem uwagę na teologiczne kontrowersje, w jakie się angażowal (arianizm, spory orygenesowskie, pelagianizm), na jego duchowość oraz dorobek naukowy. Historia polemik teologicznych została przedstawiona w sposób schematyczny, ramowy i nie dostarcza nowych danych. Czytelnik otrzymuje dość ogólny szkic tak samej problematyki, wokół której toczyły się spory, jak też zaangażowania się w nie tytułowej postaci.

Duchowość św. Hieronima została scharakteryzowana poprzez dwa wymiary: jego monastycyzm oraz relacje $z$ kobietami. W pierwszym przypadku autor koncentruje się bardziej na roli, jaką on odegrał w rozwoju życia monastycznego niż na samym jego życiu wedlug ideałów monastycznych. Trudno więc potraktować to jako pełną charakterystykę duchowości. Również intrygująca kwestia związku Hieronima ze słynnymi arystokratkami rzymskimi oraz roli, jaką odgrywał w obraniu przez nie życia monastycznego, została potraktowana w książce w sposób bardzo ogólny. Czytelnik ma okazję zapoznać się z samym fenomenem monastycyzmu, bez uwzględnienia jego genezy i szczegółów. Intrygujące nieco w tym kontekście może być pytanie o racje, dla których ta część dzieła została zatytułowana Askese.

Najobszerniej i najrzetelniej w tej części książki została ukazana sylwetka św. Hieronima jako biblisty. Właśnie on jako biblista jest dla Autora synonimem naukowca. Rzetelnie zostały przedstawione jego kwalifikacje, warsztat naukowy, a potem osiągnięcia. W tej części też spotykamy najwięcej odwołań do biografii patrona biblistów. Mimo wszystko, zrozumienie tej części książki wymaga uprzedniej znajomości biografii wielkiego Strydończyka.

Druga część książki stanowi o jej oryginalności i w dużej mierze nadaje jej wartość. Zostały tam przedstawione sylwetki osób, $z$ którymi się kontaktował św. Hieronim. Wykaz ten został sporządzony $z$ wielką skrupulatnością i starannością. Wiele $\mathrm{z}$ umieszczonych tam osób to postacie znane, ale są też takie, które gdzie indziej nie są nawet wzmiankowane. Każda informacja została 
zaopatrzona we wskazanie miejsca w dziełach biblisty z Betlejem, gdzie dana osoba występuje (najczęściej chodzi o listy św. Hieronima). Wskazana została również bibliografia - o ile takowa istnieje - umożliwiająca bliższe poznanie zarówno samej osoby, jak też jej związków ze św. Hieronimem.

$\mathrm{Na}$ trzecią część książki składają się teksty samego św. Hieronima. Jest to autorska antologia dokonana przez A. Fürsta. Wybrane przez siebie Hieronimowe teksty, Autor przyporządkowal trzem tematom, odnoszącym się do biografii, duchowości oraz pracy naukowej Strydończyka. Każdy przytoczony tekst zaopatrzony został $w$ podstawowe dane, umożliwiające jego identyfikację oraz w istotne objaśnienia, ułatwiające lepsze zrozumienie tekstu. Znaleźć tam też można wskazówki bibliograficzne.

Obszerną literaturę, dotyczącą omawianej problematyki, Autor zamieścil na końcu dzieła. Zebrana tam została obszerna bibliografia dotycząca zarówno samego Hieronima, jak też epoki, w której żył oraz problematyki, którą poruszał. Autor uszeregował zebrany materiał według pewnego klucza: najpierw przedstawił poszczególne dzieła Hieronima i pod każdym wskazał poświęconą mu współczesną literaturę. Dziela zostały uszeregowane według klucza tematycznego (listy, traktaty, literatura monastyczna, thumaczenia, homilie, komentarze). Następnie wskazana została literatura tematycznie związana z twórczością Strydończyka. Obszerna bibliografia została przyporządkowana poszczególnym rozdziałom książki. Ten sposób przedstawiania bibliografii trudno jednoznacznie ocenić. Można wnioskować, że Autorowi chodziło o ujęcie tylko tych pozycji, które są bezpośrednio związane z problematyką książki.

Starannie wydana, także pod względem edytorskim, książka $\mathrm{z}$ calą pewnością zasługuje na zauważenie i będzie stanowiła pomoc dla wszystkich zajmujących się zawodowo osobą św. Hieronima. Ci jednak, którzy dopiero wchodzą $\mathrm{z}$ nim w kontakt, muszą się wesprzeć jeszcze innymi pozycjami.

ks. Antoni Żurek - Tarnów

Jerzy Zbigniew LACHOWICZ, La mujer en la vida y el pensamiento de San Gregorio Magno (540-604). Tesis de doctorado, Pamplona 2000, Universidad de Navarra. Facultad de Teologia, ss. 512.

W dziejach całego chrześcijaństwa, jeszcze przed wielkimi podziałami, zawsze szczególnym etapem początków pozostaje cały okres starożytności. O tej wyjątkowej randze decyduje nie tylko wyjątkowa bliskość czasów Jezusa Chrystusa i szczególne świadectwo wiary, często znaczone męczeństwem, ale także powstała wówczas przebogata myśl teologiczna Ojców Kościoła i pisarzy starożytności chrześcijańskiej. To w tym okresie kształtowały się zasadnicze zręby całego chrześcijańskiego nauczania teologicznego, i to w wielu aspek- 